\title{
3 点曲げ試験片の板厚による拘束効果の影響に関する研究*
}

\author{
菊 池 正 紀 $^{* 1}$, 石 原 豪 人 $^{* 2}$ \\ Study on Thickness Effect of Three Point Bend Specimen \\ Masanori KIKUCHI*3 and Takehito ISHIHARA \\ ${ }^{* 3}$ Department of Mechanical Engineering, Tokyo University of Science, \\ 2641 Yamazaki, Noda-shi, Chiba, 278-8510 Japan

\begin{abstract}
The thickness effect of three point bend ( $3 \mathrm{~PB}$ ) specimen on dimple fracture behavior is studied experimentally and numerically. At first, fracture toughness tests were conducted using $3 \mathrm{~PB}$ specimens with different thicknesses. Fracture toughness values and $\mathrm{R}$-curves are obtained and the thickness effect is discussed. Using Scanning Electron Microscope (SEM), dimple fracture surfaces are observed precisely. It is found that the thickness effect appears clearly on the void growth process. FEM analyses are conducted based on these experimental data. Using Gurson's constituteve equation, nucleation and growth of void during dimple fracture process is simulated. The distribution patterns of stress triaxiality and crack growth process are obtained. The results show good agreement with experimetal ones qualitatively. The effect of the specimen thickness on R-curves are explained well based on these numerical simulation.
\end{abstract}

Key Words: Constraint Effect, Thickness Effect, Dimple Fracture, J-R Curve, FEM Analysis, Gurson's Constitutive Equation

\section{1. 粕言}

非線形破壊力学において, き裂先端の力学状態を 表すパラメータとして Riœによって提案された $\mathrm{J}$ 積分 が広く用いられてきた ${ }^{(1)}$.この J 積分により, き裂先 端近傍の応力状態を表す HRR 解が表記できる. しか し, 近年の実験及ひ数值解析により, 実際の忘力状態 はき裂を有する構造の形状によっては HRR 解とずれ が生じることが報告されている(2)(）。れらの問題は き裂先端の塑性域を取り囲む弾性域からの拘束の影響 という意味から拘束条件と呼ばれており, 非線形破壊 力学の基本的パラメータである $\mathrm{J}$ 積分の有用性を問う 問題である.

著者らは過去に拘束効果に関して3つの報告をし てきた. 第 1 報(4)では原子炉圧力容器用網 A533B を用 いて負荷形式，初期き裂長さ，板厚の異なる試験片を 作成し，弾塑性破壊鞋性試験により拘束効果が破面形 成や破壊勒性値へ与える影響を調べた。

\footnotetext{
* 原稿受付 2004 年 4 月 9 日.

*1 正員, 東京理科大学工学部 (正 278-8510 野田市山崎 2641).

*2 東京理科大学大学院理工研究科.

E-mail : kik@me.noda.tus.ac.jp
}

第2 報けでは，Gursonにより提案され Tvergaardによ って修正された多孔質材料の構成方程式を導入した有 限要素法を用いてディンプル破壊をシミュレーション することにより，負荷形式の違いによる拘束効果が破 面形成一与える影響を考察した.

第 3 報のでは第 2 報と同様の数値解析手法を用い, 初期き裂長さの違いによる拘束効果が J-R 曲線へ与え る影響について考察した.

しかし，板厚の違いによる拘束効果については過 去の実験からはっきりした傾向がみられておらずその ため数值解析, 考察も十分に行われていない. 本研究 では，この板厚の違いによる拘束効果が破壊に与える 影響について調べることを目的とし, 異なる板厚の 3 点曲げ試験片 $(\mathrm{B}=8 \mathrm{~mm}, 4 \mathrm{~mm}, 2 \mathrm{~mm})$ を用いて実験と数值 解析を行った. 拘束効果が破壊に与える影響は様々に あると考えられるがここでは過去の研究と同じく破壊 一の巨視的な影響として J-R 曲線や破壊靺生值 $\mathrm{ICC}$ の違 いについて, 破壊への微視的な影響として破面形成の 違いについて注目し，実験は破壊勒性試験と破面観察 を，数值解析は多孔質材料の構成方程式を用いた有限 要素法解析を行った. 


\section{2 実験}

\section{$2 \cdot 1$ 破壊䩓性訊験}

供試材は原子炉圧力容器用鋼 A533B であり, 圾験 片形状は図 1 に示すように 3 点曲げ試験片である。靭 性試験は JSME の弾塑性破壊鞀性 $\mathrm{J}_{\mathrm{C}}$ 試験法 (7)に記載さ れている R 曲線法に沿って行った.この $\mathrm{J}_{\mathrm{C}}$ 試験法で は試験片の板厚 B が次式(1)を満たすことを条件とし ている.

$$
B \geq 25 \frac{J_{\text {in }}}{\sigma_{f s}}
$$

ここで A533B 鋼の材料定数を $\mathrm{Jin}=185 \mathrm{kN} / \mathrm{m}, \quad \sigma_{\mathrm{s}}=$ $660 \mathrm{MPa}$ とする (8)と B $\geq 7.01 \mathrm{~mm}$ となる. そこで本研究 ではこの条件を満たすものとして板厚 $8 \mathrm{~mm}$, 満たさ ないものとして $4 \mathrm{~mm}, 2 \mathrm{~mm}$, 計 3 種類の試験片を用 いた.

図 2 は 3 次元弾塑性有限要素法解析により求めた $\mathrm{J}$ = $\mathrm{J}_{\mathrm{C}}$ における板厚中央部でのき裂先端応力場を HRR 解と比較したものである. $8 \mathrm{~mm}$ では HRR 解とほぼ一 致しているのに対し，4mm， $2 \mathrm{~mm}$ と板厚が薄くなる にしたがって HRR 解よりも小さくなっており，き裂 先端の拘束条件の変化から $\mathrm{J}$ 積分が支配的でなくなる ことがわかる.

実験の際， $\mathrm{J}$ 積分評価は式(2)に示す簡便評価式を用 いて行った.

$$
J=\frac{1-v^{2}}{E} K^{2}+\frac{2}{b B} \int_{0}^{\delta} p d \delta
$$

ここで, $\mathrm{K}$ は応力拡大倸数, $\mathrm{b}$ はリガメント長さ, $\mathrm{P}$ は荷重, $\delta$ は荷重線変位である. また, J-R 曲線に おけるき裂進展量 $\Delta \mathrm{a}$ は電子顕微鏡を用い, (3/8〜 $5 / 8) B$ の範囲内で $\Delta \mathrm{a}$ を 5 点測定し, その平均值を用 いた.

実験により得られた破壊勒性值を表 1 に示す。式 (1)で示した通り板厚条件を満たす試験片は $8 \mathrm{~mm}$ のみ であり，J積分が支配的でなくなる $4 \mathrm{~mm} ， 2 \mathrm{~mm}$ ではや や高い破壊勒性值になった。しかし，板厚により系統 的に変化する傾向はみられない．

$\mathrm{J}-\mathrm{R}$ 曲線を図 3 に示す. 鈍化直線には板厚による系 統的な傾向は見られない、ただし，A533B 鋼のような 高勒性材料ではストレッチゾーンと延性破壊領域の区 別がつきにくく，鈍化直線上の点にするか $\mathrm{R}$ 曲線上 の点にするかにより鈍化直線は大きく異なってしまう。 そのため実験から正しい鈍化直線を求めるためには更
に多くの試験片で破面上のストレッチゾーンをより詳 細に観察する必要がある。

$\mathrm{R}$ 曲線について注目すると， $\Delta \mathrm{a}$ の小さい範囲では 上述した通りストレッチゾーンと延性破壊領域の区別 がつきにくく、はっきりした傾向がみられない，しか し， $\Delta \mathrm{a}$ が大きくなる、つまり破壊が進むにつれて， 板厚が薄くなるほど J 積分值が小さくなる傾向が見ら れた.

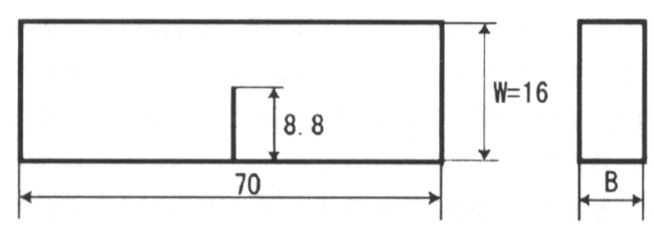

Fig. 1 Three Point Bending Specimen (3PB)

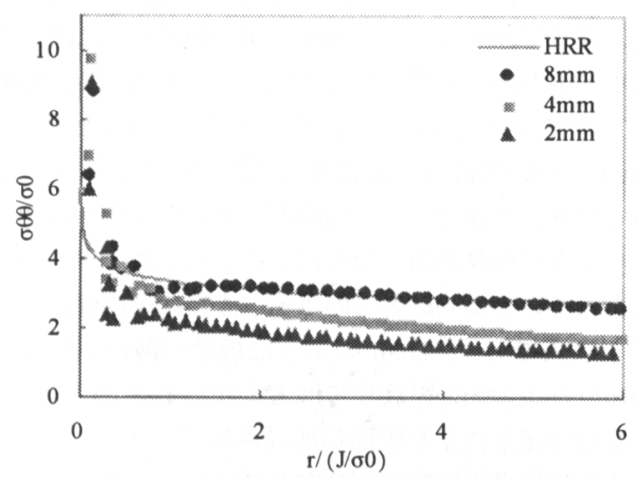

Fig. 2 Crack tip stress fields at the center of specimen

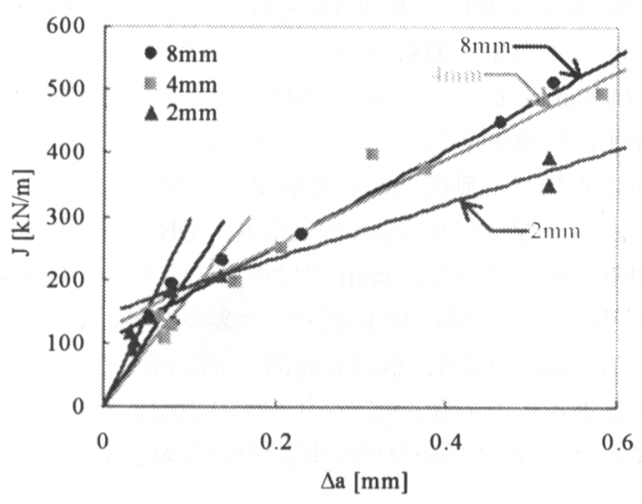

Fig. 3 J-R curves by experiments

Table $1 \mathrm{~J}_{\mathrm{IC}}$ value of three specimens

\begin{tabular}{|c|c|c|c|}
\hline Thickness $[\mathrm{mm}]$ & 8 & 4 & 2 \\
\hline $\mathrm{J}_{\mathrm{IC}}$ value $[\mathrm{kN} / \mathrm{m}]$ & 158.0 & 194.1 & 171.6 \\
\hline
\end{tabular}




\section{$2 \cdot 2$ 破面観察}

次に板厚による拘束効果が破壊一与える微視的な影 響を調べるために，破壊勒性試験で用いた試験片の破 面観察を行った.ここで破面観察には SEM(Scanning Electron Microscope)を用いた.

まず，各試験片の延性破面上に存在するボイドの大 きさを測定した．破壊はボイドだけでなく，ボイドと ボイドが合体して大きなすべりを起こしている部分も ある. また，そのボイドも小さいものでは直径 $1 \mu \mathrm{m}$ 位のものから, 大きいものは直径 $100 \mu \mathrm{m}$ 以上と大小 さまざまな大きさのボイドが存在する. そこで本研究 では, 早い段階から発生し, 破壊に大きな影響を及ぼ すと考えられる比較的大きなボイドについてのみ調べ ることとし，直径 $10 \mu \mathrm{m}$ 以上のボイドの大きさを測定 した. 表 2 に測定したボイドの平均の直径を, 図 4 に それぞれの板厚の板厚中央部付近での破面の一例を示 す. 図4に示すように，8mm の延性破面上には大き なボイドが多く観察されるのに対し，4mm では $8 \mathrm{~mm}$ よりもやや小さめのボイドが多くみられた。 また $2 \mathrm{~mm}$ においては $4 \mathrm{~mm}$ よりもさらに小さいボイドが 多くなり，大きなボイドはほとんどみられなかった。 このように板厚が薄くなるにしたがってボイドが小さ くなっていく傾向は表 2 のボイド直径の平均値におい ても同様であり，2mm のように板厚の薄い試験片， つまり拘束の弱い試験片では大きなボイドではなく， 小さなボイドにより破面が形成されていた.

き裂進展量の板厚方向分布を調べた. 図 5 は各板厚 において Jが $200 \mathrm{kN} / \mathrm{m}$ 前後でのき裂進展量の板厚方向 分布である. 実験においては板厚の違いによる破壊勒 性值 $\mathrm{J}_{\mathrm{KC}}$ の系統的な傾向は見られず， $\mathrm{J}_{\mathrm{IC}}$ はどの板厚に おいても 160〜 200kN/m 程度であった. よって J が $200 \mathrm{kN} / \mathrm{m}$ 前後というのは, 各板厚でき裂の安定破壊が 始まる初期状態であると考えられる. 図5において横 軸は各板厚で無次元化した板厚方向を示しており， $\mathrm{Y} / \mathrm{B}=0$ と $\mathrm{Y} / \mathrm{B}=1.0$ は板厚表面部を, $\mathrm{Y} / \mathrm{B}=0.5$ は板厚中 央部を示している. $8 \mathrm{~mm}$ では板厚中央部から板厚表 面部にかけて比較的広い範囲でき裂が進展している.

一方 $2 \mathrm{~mm}$ の場合, 板厚表面部付近においてせん断型 の破壊形式であるシェアーリップの領域が大きくなっ ており，板厚中央部の狭い範囲でのみ大きくき裂が進 展していた。

Table 2 Average of dimple diameters

\begin{tabular}{|c|c|c|c|}
\hline Thickness $[\mathrm{mm}]$ & 8 & 4 & 2 \\
\hline Diameter $[\mu \mathrm{m}]$ & 22.2 & 17.7 & 17.0 \\
\hline
\end{tabular}

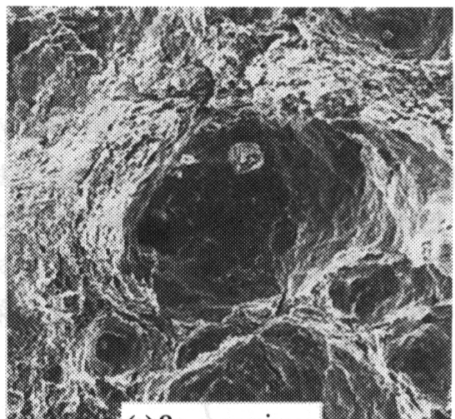

(a) $8 \mathrm{~mm}$ specimen
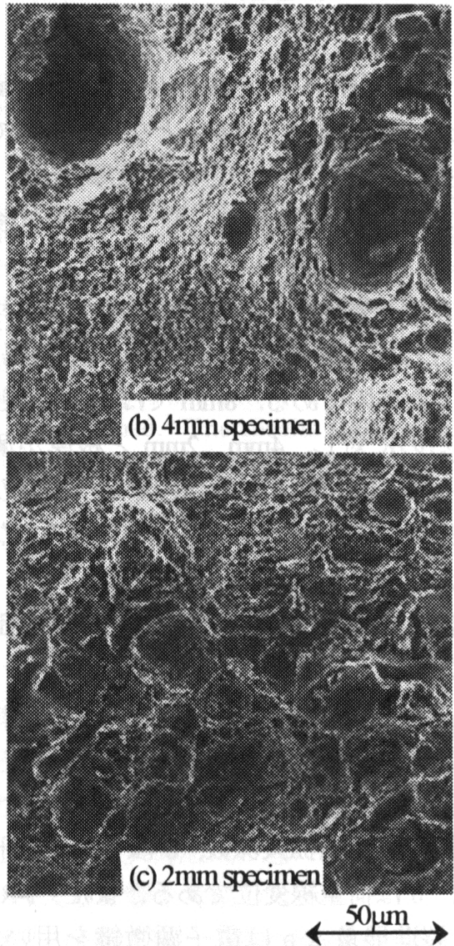

Fig.4 Fracture surface photos

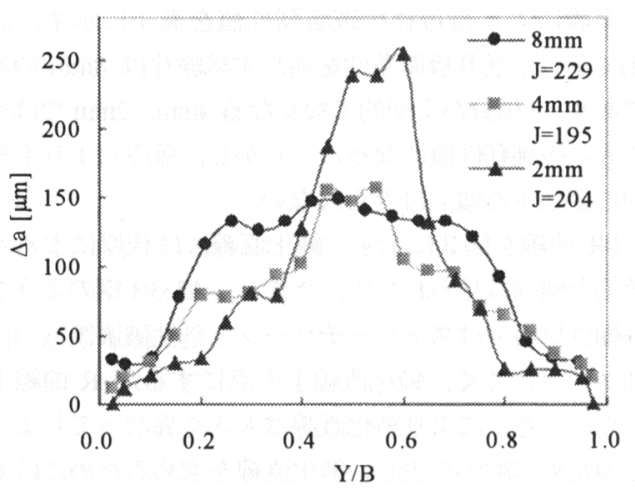

Fig. 5 Crack growth amount along the crack tip 


\section{3. 有 限 要 素 法 解 析}

\section{3·1 Gurson の構成方程式}

実験でみられたような板厚による拘束効果が破壊 に与える影響を調べるため, 有限要素法解析を行った ここではディンプル破壊をシミュレートするため, Gurson により提案され Tvergaardによって修正された 多孔質材料の降伏関数 ${ }^{(9)}$ 式(3)を用いている.

$$
\Phi=\frac{3}{2} \frac{\sigma_{i j}^{\prime} \sigma_{i j}^{\prime}}{\bar{\sigma}_{m}^{2}}+2 f q_{1} \cosh \left(\frac{q_{2} \sigma_{k k}}{2 \bar{\sigma}_{m}}\right)-\left(1+q_{3} f^{2}\right)=0
$$

ここで式中の $\sigma^{\prime} \boldsymbol{y}$ は偏差応力, $\bar{\sigma}_{m}$ は相当応力, $f$ はボイド率, $q_{1}, q_{2}, q_{3}$ は Tvergaardによって定められ た定数である. また, ボイド率の増分は式(4)のよう に, 式(5)に示寸成長項と式(6)に示寸発生項からなる.

$$
\begin{aligned}
& \dot{f}=(\dot{f})_{\text {growth }}+(\dot{f})_{\text {mucleation }} \\
& (\dot{f})_{\text {growth }}=(1-f) \dot{\bar{\varepsilon}}_{k k}^{p} \\
& (\dot{f})_{\text {mucleation }}=A\left(\dot{\bar{\sigma}}+\dot{\sigma}_{k k} / 3\right)+B \dot{\bar{\varepsilon}}_{m}^{p}
\end{aligned}
$$

ここで，ボイドの発生には相当塑性ひずみ支配を 用いているので A，Bは式(7)のようなる.

$$
B=\frac{f_{N}}{S_{N} \sqrt{2 \pi}} \exp \left[-\frac{1}{2}\left(\frac{\bar{\varepsilon}_{m}^{p}-\varepsilon_{N}}{S_{N}}\right)^{2}\right], A=0
$$

$f_{N}$ はボイドの発生に寄与寸る介在物の体積含有量, $S_{N}$ はボイド発生を確率的に制御するための標準偏差, $\varepsilon_{N}$ はボイドが発生する際の平均的な歪み量である.

\section{$3 \cdot 2$ 解析モデル}

Gursonモデルはパラメータが非常に多いので，これ らのパラメータの值をどのように決定するがついて は種々の方法が提案されている(10)(1)(2) . また，損傷解 析においてはき裂先端近傍の要素形状依存性を少なく するためき裂先端近傍の要素分割を細かく，一定にす る必要がある.

ここでは実験との定量的な比較を目的とするのでは なく，定性的な比較を目的とすることとし，材料定数 は表 3 に示す通りすべて同じものを用いた ${ }^{(33)(4)}$ ．また き裂先端での要素の最小寸法は, 計算機の容量や過去 の経験などをふまえて $0.025 \mathrm{~mm}$ とし, どの板厚のモ デルでもき裂先端付近については同様のモデルを用い ている.

解析に用いたモデルの全体図を図6(a)に，き裂先端 付近の挔大図を図 6 (b)に示す。モデルは対象性を考
慮して $1 / 4$ モデルとした. 図 6(b)の右側は試験片中央 部の対称面であり、左側はき裂面を示している。図の 左端でき裂面が試験片表面と交差している．また，各 モデルの節点数, 要素数は表 4 に示すとおりである.

要素はスーパーボックス要素を用いている. 実験にお いて疲労予き裂を導入する際き裂は板厚中央部で先行 するので，き裂縁形状は直線とせず、各板厚の試験片 のき裂菉形状をそれぞれ 3 本づつ実測し，その平均の 形状を解析モデルとして用いた.

破壊解析はボイド率が破壊ボイド率に達した要素を 消去することで行った。

Table 3 Material properties (A533B steel)

\begin{tabular}{|c|c|c|}
\hline Young's modulus & $\mathrm{E}$ & $206[\mathrm{GPa}]$ \\
\hline Poisson's ratio & $\mathrm{v}$ & 0.3 \\
\hline Initial yield stress & $\sigma_{\mathrm{ss}}$ & $599[\mathrm{GPa}]$ \\
\hline Critical void volume fraction & $\mathrm{f}_{\mathrm{c}}$ & 0.133 \\
\hline Void volume fraction at final & $\mathrm{f}_{\mathrm{f}}$ & 0.188 \\
\hline $\begin{array}{c}\text { Volume fraction of void nucleating } \\
\text { particles }\end{array}$ & $\mathrm{f}_{\mathrm{N}}$ & 0.02 \\
\hline Standard deviation of void nucleation & $\mathrm{S}_{\mathrm{N}}$ & 0.1 \\
\hline Mean strain for void nucleation & $\varepsilon_{\mathrm{N}}$ & 0.3 \\
\hline
\end{tabular}

Table 4 Mesh size

\begin{tabular}{|c|c|c|}
\hline & Nodes & Elements \\
\hline $8 \mathrm{~mm}$ & 474028 & 92900 \\
\hline $4 \mathrm{~mm}$ & 247298 & 48230 \\
\hline $2 \mathrm{~mm}$ & 134568 & 26020 \\
\hline
\end{tabular}

(a) Whole Mesh

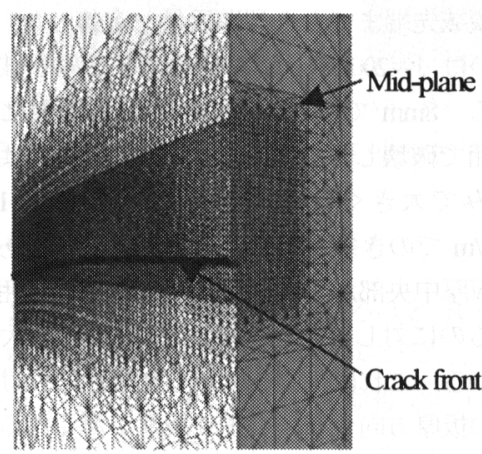

(b) Crack tip

Fig. 6 Mesh pattern of 3PB Specimen ( $8 \mathrm{~mm})$ 


\section{$3 \cdot 3$ 破面形成一の影響}

図 7 に示すのは破壊開始直後でのき裂先端部付近に おける応力三軸度分布である. 応力三軸度は静水圧成 分を相当応力で割ったものである. $8 \mathrm{~mm}, 4 \mathrm{~mm}, 2 \mathrm{~mm}$ と板厚が薄くなるにしたがって応力三軸度の高い部分 が狭く, その值も小さくなっている，図8はこのとき のき裂先端から $0.1 \mathrm{~mm} ， 0.4 \mathrm{~mm}$ における応力三軸度板 厚方向分布である. 横軸は各板厚で無次元化した板厚 方向を示しており, $\mathrm{Y} / \mathrm{B}=0$ が板厚表面部, $\mathrm{Y} / \mathrm{B}=0.5$ が 板厚中央部を示している. どちらの位置でも $8 \mathrm{~mm}$, $4 \mathrm{~mm}, 2 \mathrm{~mm}$ の順に応力三軸度が低くなっている. ま た，8mm では板厚中央部から表面部にかけて広い範 囲で応力三軸度が高いのに対し，2mm では板厚中央 部の狭い範囲でのみ応力が高くなっており，これから も板厚が薄くなるほど応力三軸度の高い範囲が狭くな ることがわかる.

応力三軸度はボイドの発生, 成長に大きな影響をも つ.つまり,この応力三軸度が高い領域ではボイドが 発生, 成長しやくなる. $8 \mathrm{~mm}$ ではき裂進展方向, 板 厚方向ともに広い範囲で応力三軸度が高くなっている. よってき裂先端部で発生したボイドは大きく成長し、 それら大きなボイドが合体することにより破面が形成 されると考えられる. 一方 $2 \mathrm{~mm}$ ではき裂進展方向, 板厚方向ともに応力三軸度の高い範囲が狭く, またそ の值も $8 \mathrm{~mm}$ に比べて低い. よって板厚中央部付近の 狭い範囲で発生したボイドは大きく成長することがで きず，小さなボイドが連結することで破面が形成され ると考えられる. これは表 2 の実験結果において板厚 が薄くなるほどボイドの平均直径が小さくなっていた ことと対応していると考えられる.

図 9 には数值解析におけるき裂進展量の定義を示す. 解析モデルに設定した初期き裂先端の曲率の底部から 破壊領域先端までをき裂進展量と定義した. 図 10 に 示すのは $\mathrm{J} \fallingdotseq 200 \mathrm{kN} / \mathrm{m}$ におけるボイド率と破壊の様子 である. $8 \mathrm{~mm}$ では板厚中央部から表面部にかけて広 い範囲で破壊しているのに対し，2mm では板厚中央 部のみで大きく破壊が進んでいる. 図 11 は $\mathrm{J} \fallingdotseq$ $200 \mathrm{kN} / \mathrm{m}$ でのき裂進展量の板厚方向分布である. $8 \mathrm{~mm}$ では板厚中央部から表面部にかけて広い範囲で破壊し ているのに対し，2mm では板厚中央部で大きく破壊 している.これは, 図5に示した実験におけるき裂進 展量の板厚方向分布, つまり板厚が薄くなるほど板厚 中央部の狭い範囲でのみ破壊が大きく進むことと対応 している.
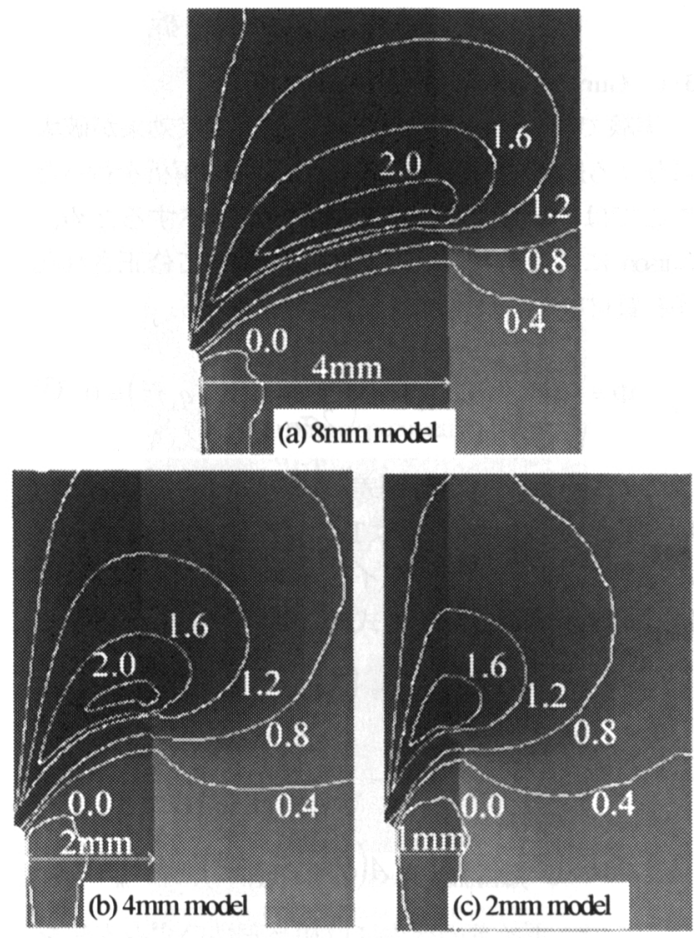

Fig.7Distribution of stress triaxiality

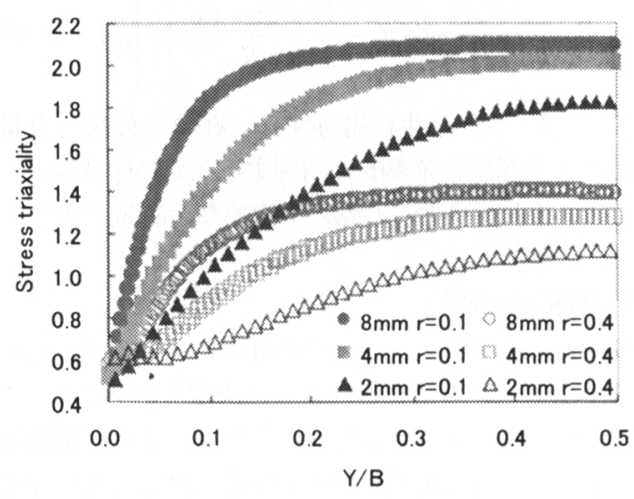

Fig. 8 Stress triaxiality along the crack tip

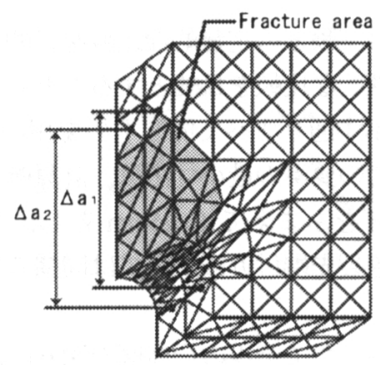

Fig.9 Definition of crack growth amount 


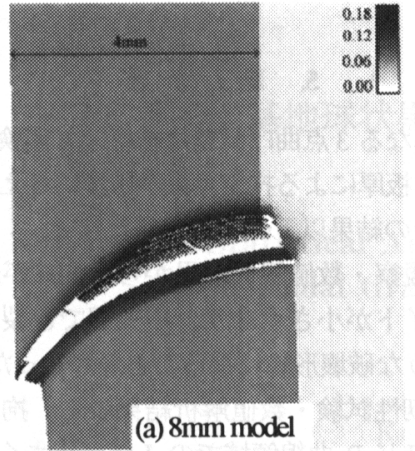

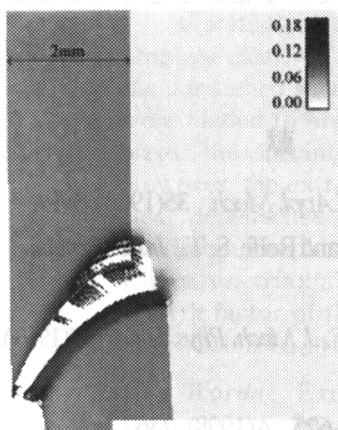

(b) $4 \mathrm{~mm}$ model

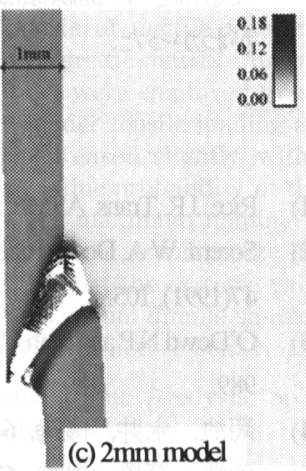

(c) $2 \mathrm{~mm}$ model
Fig.10 Distribution of void volume fraction

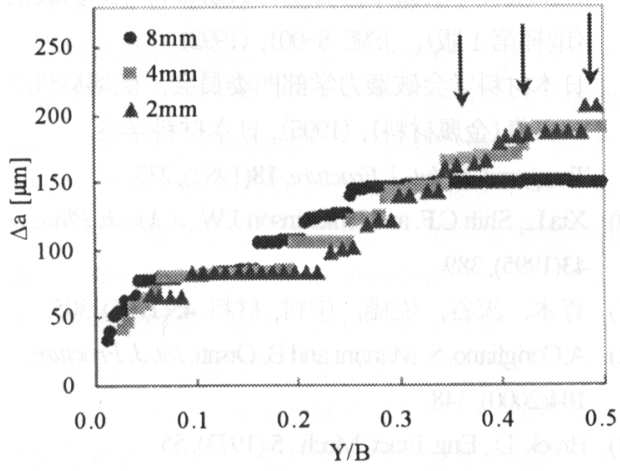

Fig. 11 Fracture pattern along the crack tip

\subsection{J-R曲線への影響}

図 12 は $\mathrm{J}$ 積分とき裂進展量 $\Delta \mathrm{a}$ の関係である.J積 分は実験と同様，簡便評価式を用い， $\Delta \mathrm{a}$ は実験の $\mathrm{J}$ $\mathrm{R}$ 曲線と対応する位置での平均值とした。

図 13 には $8 \mathrm{~mm}$ 試験片の試験片中央部での破壊の進 展の様子を示す．き裂進展開始の初期, $\Delta \mathrm{a}=0.1 \mathrm{~mm}$ あたりまでのき裂進展は，図 13(a)のようにき裂先端 の開口とき裂先端部付近の破壊により生じる. そのた めこの部分は実験における鈍化直線に対応していると 考えられる. その後, 破壊は図 13(b)の上うに初期き
裂方向に進展しており，これは $\mathrm{R}$ 曲線に対応してい ると考えられる.

図 12 をみると $\Delta \mathrm{a}=0.1 \mathrm{~mm}$ あたりまでは板厚が薄く なるほど Jがわずかに小さくなっていく傾向がみられ るが，破壊要素にははっきりした違いはみられなかっ た. 一方 $\Delta \mathrm{a}=0.1 \mathrm{~mm}$ 以降では破壊が進行するにつれ て $2 \mathrm{~mm}$ の $\mathrm{J}$ 積分值が小さくなっていく傾向がみられ る. このように板厚が薄くなるにつれ $\mathrm{J}$ 積分值が小さ くなる傾向は，図3に示した実験結果の $\mathrm{R}$ 曲線にお いても同様であり，数值解析においても実験と定性的 に一致した J-R曲線が得られた.

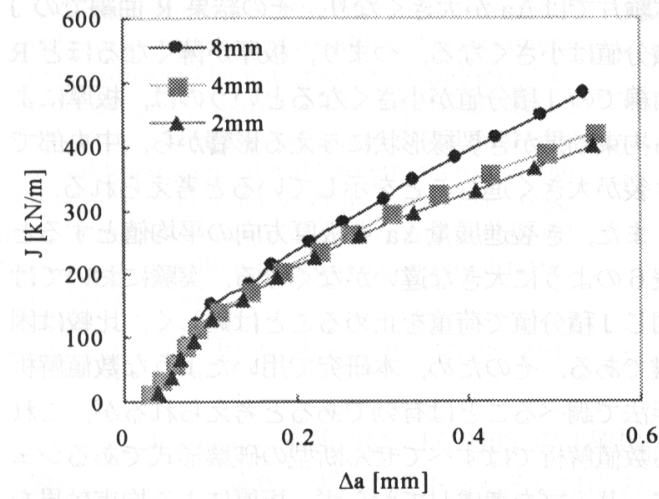

Fig.12 Apparent J-R curves by analysis

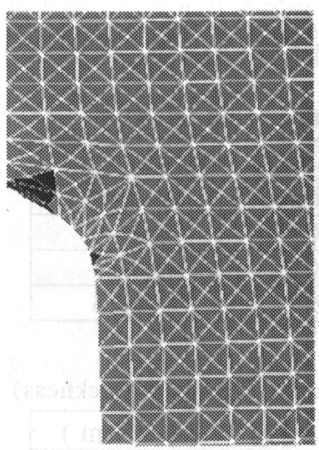

(a) $\Delta \mathrm{a}=0.1$

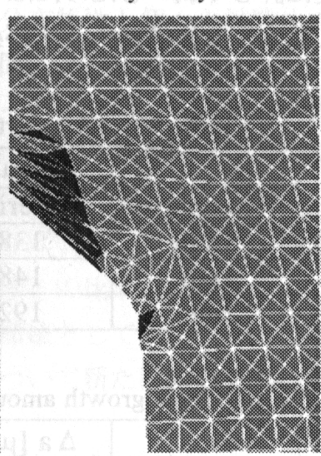

(b) $\Delta \mathrm{a}=0.2$
Fig. 13 Fracture pattern at the center of specimen

\section{4. 考察}

実験，数值解析から板厚が薄くなるほど $\mathrm{R}$ 曲線領 域での J 積分值が小さくなる傾向がみられた．そこで なぜこのように板厚が薄くなると $\mathrm{R}$ 曲線での $\mathrm{J}$ 積分值 が小さくなるのかを考察する. 図 5, 図 11 で示した ように同じエネルギ状態，例えば Jが $200 \mathrm{kN} / \mathrm{m}$ 前後で $8 \mathrm{~mm}$ と $2 \mathrm{~mm}$ の板厚方向のき裂進展量を比較すると, 実験，数值解析どちらにおいても，2mm の板厚中央 
部付近におけるき裂進展量は $8 \mathrm{~mm}$ よりも大きくなっ ているが, 表面部に近づくにつれ 8mm よりもき裂進 展量は小さくなっていく.これは板厚の薄い $2 \mathrm{~mm}$ で は拘束の変化が大きいためであり，そのためこのよう に中央部で先行するき裂形状になると考えられる.

表 5 は実験と数值解析における $\mathrm{J} \doteqdot 200 \mathrm{kN} / \mathrm{m}$ での $\Delta \mathrm{a}$ である．本研究では， J-R 曲線における $\Delta \mathrm{a}$ を Y/B=0.375 0.625 の範囲内で 5 点測定したき裂進展量 の平均值とした. そのため $\Delta \mathrm{a}$ は, 例えば図 11 の矢 印に示すように板厚中央部付近での平均値となる. よ って表 5 のように中央部でき裂が先行する板厚の薄い 試験片では $\Delta \mathrm{a}$ が大きくなり，その結果 $\mathrm{R}$ 曲線での $\mathrm{J}$ 積分值は小さくなる. つまり，板厚が薄くなるほど R 曲線での $\mathrm{J}$ 積分值が小さくなるというのは，板厚によ る拘束効果がき裂縁形状に与える影響から，中央部で き裂が大きく進むことを示していると考えられる.

また, き裂進展量 $\Delta \mathrm{a}$ を板厚方向の平均値とすると 表 6 のように大きな違いがなくなる．実験においては 同じ $\mathrm{J}$ 積分值で荷重を止めることは難しく，比較は困 難である. そのため, 本研究で用いたような数値解析 手法で調べることは有効であると考えられるが，これ ら数值解析ではすべてせん断型の破壊形式であるシェ アーリップを考慮しておらず，板厚による拘束効果を 更に詳しく調べるためにはせん断型の破壊形式も考慮 したような数值解析手法が必要であると考えられる.

Table 5 Crack growth amount ( $\mathrm{J}_{\mathrm{IC}}$ test)

\begin{tabular}{|c|c|c|}
\hline & \multicolumn{2}{|c|}{$\Delta \mathrm{a}[\mu \mathrm{m}](\mathrm{J} \doteqdot 200 \mathrm{kN} / \mathrm{m})$} \\
\hline Thickness & Experiment & Analysis \\
\hline $8 \mathrm{~mm}$ & 138.3 & 149.6 \\
\hline $4 \mathrm{~mm}$ & 148.0 & 182.4 \\
\hline $2 \mathrm{~mm}$ & 192.0 & 190.3 \\
\hline
\end{tabular}

Table 6 Crack growth amount (Average of thickness)

\begin{tabular}{|c|c|c|}
\hline & \multicolumn{2}{|c|}{$\Delta \mathrm{a}[\mu \mathrm{m}](\mathrm{J} \doteqdot 200 \mathrm{kN} / \mathrm{m})$} \\
\hline Thickness & Experiment & Analysis \\
\hline $8 \mathrm{~mm}$ & 92.6 & 119.3 \\
\hline $4 \mathrm{~mm}$ & 74.8 & 124.4 \\
\hline $2 \mathrm{~mm}$ & 83.3 & 125.6 \\
\hline
\end{tabular}

\section{5. 結言}

板厚の異なる 3 点曲げ試験片を用いて実験と数值解 析を行い，板厚による拘束効果が破壊に与える影響を 調べた. その結果以下の結論を得た。

（1）破面観察・数值解析結果から, 拘束が弱くなる とボイドが小さくなり，中央部でき裂が先行す るような破壊形式になることがわかった.

（2）破壊勒性試験・数値解析結果から，拘束が弱く なるほど R 曲線領域での $\mathrm{J}$ 值が小さくなること がわかつた.

\section{文献}

(1) Riœ, J.R,Trans. ASME, JAppl. Mech. , 35(1968), 379.

(2) Sorem. W.A, Dodds RH. and Rolfe. S. T., Int. J. Fracture, 47(1991), 105.

(3) O'Dowd N.P and Shih C.F., J. Mech. Phys. Solids, 39(1991), 989.

(4) 菊池, 永井, 機論, 64-625, A(1998), 2367.

(5) 菊池, 高橋, 機論, 67-656, A(2001), 665 .

(6) 㐘池，佐々木，機論，69-687, A(2003),1621

（7）日本機械学会基準，弾塑性破壊靾性 JIC 試験法 (増補第 1版)，JSME S-001，(1992）

(8) 日本材料学会破壊力学部門委員会, 破壊靾性デ 一夕集(金属材料), (1995), 日本材料学会.

(9) Tvergaard V, Int. J. Fracture, 18(1982), 237.

(10) Xia L., Shih C.F. and Hutchinson J.W., J. Mech. Phys., 43(1995), 389

(11) 青木, 天谷, 佐橋, 中村, 材料, 45(1990), 305.

(12) A.Corigliano, S. Mariani and B. Orsati, Int. J. Fracture, 104(2000), 348.

(13) Broek, D., Eng. Fract. Mech, 5 (1973), 55

(14) 菊池、宮本、大豊、黒田、機論、56-523, A(1990), 589 